\title{
RESEARCH
}

Open Access

\section{A novel small molecule CXCR4 antagonist potently mobilizes hematopoietic stem cells in mice and monkeys}

Xiao Fang ${ }^{1}$, Xiong Fang ${ }^{1}$, Yujia Mao ${ }^{1}$, Aaron Ciechanover ${ }^{2,3,4}$, Yan $\mathrm{Xu}^{1,3,4}$, Jing $\mathrm{An}^{5^{*}}$ and Ziwei Huang ${ }^{1,4,5^{*}}$

\begin{abstract}
Background: Hematopoietic stem cell (HSC) transplantation is an effective treatment strategy for many types of diseases. Peripheral blood (PB) is the most commonly used source of bone marrow (BM)-derived stem cells for current HSC transplantation. However, PB usually contains very few HSCs under normal conditions, as these cells are normally retained within the BM. This retention depends on the interaction between the CXC chemokine receptor 4 (CXCR4) expressed on the HSCs and its natural chemokine ligand, stromal cell-derived factor (SDF)-1a (also named CXCL12) present in the BM stromal microenvironment. In clinical practice, blocking this interaction with a CXCR4 antagonist can induce the rapid mobilization of HSCs from the BM into the PB.

Methods: $\mathrm{C} 3 \mathrm{H} / \mathrm{HEJ}, \mathrm{DBA} / 2, \mathrm{CD} 45.1^{+}$, and $\mathrm{CD} 45.2^{+}$mice and monkeys were employed in colony-forming unit (CFU) assays, flow cytometry assays, and competitive/noncompetitive transplantation assays, to assess the short-term mobilization efficacy of HF51116 and the long-term repopulating (LTR) ability of HSCs. Kinetics of different blood cells and the concentration of HF51116 in PB were also explored by blood routine examinations and pharmacokinetic assays.
\end{abstract}

Results: In this paper, we report that a novel small molecule CXCR4 antagonist, HF51116, which was designed and synthesized by our laboratory, can rapidly and potently mobilize HSCs from BM to PB in mice and monkeys. HF51116 not only mobilized HSCs when used alone but also synergized with the mobilizing effects of granulocyte colony-stimulating factor (G-CSF) after co-administration. Following mobilization by HF51116 and G-CSF, the longterm repopulating (LTR) and self-renewing HSCs were sufficiently engrafted in primary and secondary lethally irradiated mice and were able to rescue and support long-term mouse survival. In monkeys, HF51116 exhibited strong HSC mobilization activity and quickly reached the highest in vivo blood drug concentration.

Conclusions: These results demonstrate that HF51116 is a new promising stem cell mobilizer which specifically targets CXCR4 and merits further preclinical and clinical studies.

Keywords: Hematopoietic stem cell mobilization, CXCR4 antagonist, Monkeys, Hematopoietic stem cell transplantation

\footnotetext{
* Correspondence: jan@health.ucsd.edu; zwhny@yahoo.com

${ }^{5}$ Division of Infectious Diseases and Global Public Health, Department of Medicine, School of Medicine, University of California at San Diego, La Jolla,

CA, USA

${ }^{1}$ School of Life Sciences, Tsinghua University, Beijing, China

Full list of author information is available at the end of the article
}

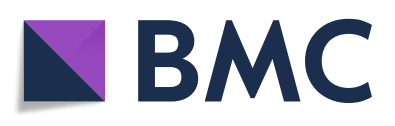

(- The Author(s). 2021 Open Access This article is licensed under a Creative Commons Attribution 4.0 International License, which permits use, sharing, adaptation, distribution and reproduction in any medium or format, as long as you give appropriate credit to the original author(s) and the source, provide a link to the Creative Commons licence, and indicate if changes were made. The images or other third party material in this article are included in the article's Creative Commons licence, unless indicated otherwise in a credit line to the material. If material is not included in the article's Creative Commons licence and your intended use is not permitted by statutory regulation or exceeds the permitted use, you will need to obtain permission directly from the copyright holder. To view a copy of this licence, visit http://creativecommons.org/licenses/by/4.0/. The Creative Commons Public Domain Dedication waiver (http://creativecommons.org/publicdomain/zero/1.0/) applies to the data made available in this article, unless otherwise stated in a credit line to the data. 


\section{Background}

CXC chemokine receptor 4 (CXCR4) [1] belongs to the superfamily of G-protein-coupled receptors (GPCRs) [2, 3] and has stromal cell-derived factor (SDF)- $1 \alpha$ or CXCL12 as its natural ligand. The binding of hematopoietic stem cell (HSC)-expressing CXCR4 to microenvironmental SDF- $1 \alpha$ causes transmission of signals to intracellular biological pathways $[4,5]$ that mediate many intracellular processes. The end result is HSC retention and proliferation in the hematopoietic organ bone marrow (BM) [6-8]. CXCR4 knockout mice show a severe deficiency in hematopoiesis [9], and this disruption of the SDF-1 $\alpha /$ CXCR4 axis has contributed to the discovery and application of an effective HSC-mobilizing strategy [10-12].

HSCs are uncommitted cells and have the ability of selfrenewal, differentiation into specialized hematopoietic cells, and reconstitution of the bone marrow. Traditionally, pre-transplant mobilization of HSCs was performed using granulocyte colony-stimulating factor (G-CSF) with or without chemotherapy [13, 14]. G-CSF can downregulate SDF- $1 \alpha$ and promote HSC release to the PB $[12,15]$. However, in order to collect sufficient quantity of HSCs, G-CSF-based mobilization requires multiple doses over a number of days, which is known to alter the function of the HSC niche, as well as bone formation, and can cause bone pain and spleen enlargement [16]. In addition, there is approximately $25 \%$ of failure rate in patients with the use of G-CSF with or without chemotherapy even when remobilizations are performed [17]. Inadequate or interindividual variable numbers of HSCs can lead to delayed or failed engraftment, prolonged thrombocytopenia or neutropenia, increased infectious complications, and subsequently prolonged hospital stay or death [18-20]. These issues of G-CSF prompted the efforts to develop other HSC mobilization strategies based on targeted therapeutics. AMD3100 is a clinically approved CXCR4 antagonist used for HSC mobilization [21, 22]. When AMD3100 is used alone, approximately one-third of patients fail to mobilize the minimally acceptable amount of CD34positive cells needed for allogeneic transplantation [23], and AMD3100 is often used in combination with G-CSF. In view of these, there is still the clinical need for new and effective therapeutics for HSC mobilization.

In the present study, we report the in vivo HSC mobilization efficacy of HF51116 [24], a novel CXCR4 antagonist developed recently by our laboratories. HF51116 possesses a very high CXCR4 binding affinity $\left(\mathrm{IC}_{50}=12 \mathrm{nM}\right)$ [25] and potently mobilizes HSCs from the bone marrow $(\mathrm{BM})$ to the peripheral blood (PB). We have evaluated the efficacy of HF51116 in mice and monkeys, which demonstrates its potential as a new promising CXCR4 antagonist for clinical application in HSC transplantation.

\section{Methods}

\section{Compound}

Of the series of CXCR4 antagonists designed, we synthesized and identified a novel lead small molecule compound HF51116. The purity (>98\%) of HF51116 was checked by analytical high-performance liquid chromatography (HPLC), while the molecular weight (522.73 Da) and identity $\left(\mathrm{C}_{29} \mathrm{H}_{46} \mathrm{~N}_{8} \mathrm{O}\right)$ of HF51116 were determined by high-resolution mass spectrometry (HRMS) and nuclear magnetic resonance (NMR).

\section{Mice}

All mice were housed at the laboratory animal facility that had been accredited by AAALAC (Association for Assessment and Accreditation of Laboratory Animal Care International) and the IACUC (Institutional Animal Care and Use Committee) of Tsinghua University. Mouse animal protocols were approved by the laboratory animal facility. C57BL/6, C3H/HEJ, and DBA/2 mice were purchased from Charles River. We obtained B6.SJL-Ptprc ${ }^{a}$ Pepc $^{b} /$ BoyJ mice from Dr. Li Wu's Lab (School of Life Science, Tsinghua University).

\section{Monkeys}

Male rhesus macaques (4-6 years old) were housed in individual cages at the Institute of Laboratory Animals Science, Chinese Academy of Medical Sciences (CAMS) and Peking Union Medical College (PUMC), which had been accredited by AAALAC. The protocol was approved by the same institute with IACUC number XC19006.

\section{Colony-forming unit assay}

The $\mathrm{PB}$ samples were obtained from mice and rhesus monkeys following injections of AMD3100, HF51116, and/or G-CSF. Ammonium chloride solution was used to remove the red blood cells. The remaining cells in suspension were cultured in MethoCult ${ }^{\text {ti }}$ GF M3434 or MethoCult $^{\text {tm }}$ H4434 (STEMCELL Technologies) in a humidified atmosphere. The total numbers of colonyforming unit (CFU)-granulocyte-macrophage (CFUGM), burst-forming unit-erythroid (BFU-E), and multipotential colony-forming unit-granulocyte, erythroid, megakaryocyte, and macrophage (CFU-GEMM) colonies were enumerated post $8-13$ days of culture by the standard morphological criteria [26].

\section{Flow cytometry assay}

Surface antigens were quantified by flow cytometry using ZE5 Cell Analyzer (Bio-Rad) and BD FACSAria ${ }^{\mathrm{m}}$ III (BD). PE-labeled mouse anti-human CD34 [27], FITClabeled mouse anti-mouse CD45.1, FITC-labeled mouse anti-NHP CD45, V450 mouse lineage antibody cocktail 
with isotype control, PE-labeled mouse anti-mouse CD45.2, FITC-labeled hamster anti-mouse CD48, PE$\mathrm{Cy}^{\mathrm{Tm}}$ 7-labeled rat anti-mouse Ly-6A/E, APC-labeled rat anti-mouse CD117 (BD Biosciences), and PE-labeled anti-mouse CD150 (SLAM) (BioLegend) antibodies were used in the flow cytometry assays.

\section{Long-term repopulating assay}

The F1 generation (CD45.1/CD45.2) of the C57BL/6 and B6.SJL-Ptprc ${ }^{a}$ Pepc $^{b} /$ BoyJ crosses served as recipients. In the first repopulation competitive assay, G-SCF $(100 \mu \mathrm{g} /$ $\mathrm{kg}$, every $12 \mathrm{~h}$ for 4 days; Ohtemachi, Chiyoda-ku, Tokyo, Japan) was subcutaneously injected into CD $45.2^{+}$ mice. At $12 \mathrm{~h}$ post-final G-CSF injection, saline, $5 \mathrm{mg} / \mathrm{kg}$ HF51116, or $5 \mathrm{mg} / \mathrm{kg}$ AMD3100 (C-aring, Wuhan, China) was subcutaneously injected. WBCs were isolated immediately, $30 \mathrm{~min}$ ( $\mathrm{min}$ ), and $1 \mathrm{~h}$ after injection in each group. CD45.1 $1^{+} \mathrm{BM}$ cells were also isolated. The competitor cell number (CD45.1 $1^{+}$cells) was $0.5 \times 10^{6}$, and the donor cell number (CD45.2 ${ }^{+}$cells) was $1.0 \times 10^{6}$. Cell suspension, $1.5 \times 10^{6}$ cells, was intravenously injected into lethally irradiated CD45.1/CD45.2 mice (11 Gy, 5.5 Gy split dose, $2 \mathrm{~h}$ apart, radiation rate 1.05 $\mathrm{Gy} / \mathrm{min}$ ). The percentages of CD $45.2^{+}$cells were checked every month for 6 months. At that time, the noncompetitive assay was performed to determine the secondary repopulation. Briefly, lethally irradiated CD45.1/CD45.2 mice received the BM cells from each group of recipients. The percentages of $\mathrm{CD} 45.2^{+}$cells were also checked.

\section{Pharmacokinetic assays}

HF51116 was s.c. injected into rhesus monkeys at 1 and $10 \mathrm{mg} / \mathrm{kg}$. The concentration of HF51116 in serum was checked by LC-MS (Thermo Fisher, CA). ACQUITY UPLC BEH C18 column $(2.1 \times 100 \mathrm{~mm}, 1.7 \mu \mathrm{m}$, Waters $)$ was used to separate the extracts. The binary solvent system included mobile phase A $(0.1 \%$ formic acid and $5 \mathrm{mM}$ ammonium acetate in $100 \% \mathrm{H}_{2} \mathrm{O}$ ) and mobile phase B (100\% acetonitrile). A 10-min gradient with $250 \mu \mathrm{L} / \mathrm{min}$ flow rate was used as follows: $0-1.5 \mathrm{~min}, 2 \%$ B; $1.5-5 \mathrm{~min}, 2-98 \% \mathrm{~B}$; 5-7 $\mathrm{min}, 98 \% \mathrm{~B}$; 7-7.1 $\mathrm{min}, 2 \%$ $\mathrm{B}$; and $7.1-10 \mathrm{~min}, 2 \% \mathrm{~B}$. Data acquired in selected reaction monitoring (SRM) for HF51116 with transitions of 523.5/161.

\section{Blood routine examination}

All blood samples underwent blood routine examination using a ProCyte Dx Hematology Analyzer (IDEXX).

\section{Statistical analysis}

Prism (GraphPad) and Xcalibur (Thermo Fisher, CA) were used for one-way ANOVA, two-way ANOVA analysis, and descriptive statistics. Data were shown as mean \pm SEM. The flow cytometry data were processed by FlowJo (FLOWJO).

\section{Results \\ Mobilization of different peripheral blood cells in mice}

Through our extensive research efforts over many years, we have developed a new class of small molecule agents that are potent antagonists of CXCR4. On the basis of our representative compound HF50731 [28], we have developed a new highly potent small molecule analog named HF51116, which features an unsymmetrical polyamine (Fig. 1a). HF51116 binds strongly to CXCR4 with the $\mathrm{IC}_{50}$ of $12 \mathrm{nM}$ in competitive binding with $12 \mathrm{G} 5$ [25]. We examined the compositions and dynamics of different $\mathrm{PB}$ cells in mice following subcutaneous injection of HF51116. The PB showed time-dependent changes in WBCs and neutrophils in response to HF51116. At $5 \mathrm{mg} / \mathrm{kg}$, total WBC numbers in $\mathrm{PB}$ achieved a maximum number $(18.83 \mathrm{~K} / \mu \mathrm{L})$ at $60 \mathrm{~min}$ post HF51116 injection (Fig. 1b). Increases in neutrophil numbers occurred faster and lasted longer when compared to $0 \mathrm{~min}(0.50 \mathrm{~K} / \mu \mathrm{L})$, with increases of approximately 9-fold occurring from $30 \mathrm{~min}$ to $2 \mathrm{~h}$ after HF51116 treatment and 3.6-fold increases observed at 4 h (Fig. 1c). The lymphocyte numbers (Fig. 1d) started to increase at 30 to $60 \mathrm{~min}$, followed by a dramatic decrease at 1 to $4 \mathrm{~h}$. At the same dose and time post-injection of HF51116 and AMD3100, HF51116 escalated more WBCs and lymphocytes in PB (Fig. 1b, d). No changes were observed in platelet numbers in the $\mathrm{PB}$ in response to HF51116 injection, when compared to $0 \mathrm{~min}$ (Fig. 1e, $816.83 \mathrm{~K} / \mu \mathrm{L}$ ), suggesting that HF51116 specifically mobilized WBCs.

\section{Rapid mobilization of hematopoietic progenitor cells (HPCs) in mice}

We demonstrated that the HPC mobilization induced by HF51116 was dose and time dependent (Fig. 2a-d). At 1 $h$ post-injection of HF51116, the colony numbers reached a plateau at $5 \mathrm{mg} / \mathrm{kg}$, with no further increase at $10 \mathrm{mg} / \mathrm{kg}$ and $20 \mathrm{mg} / \mathrm{kg}$ (Fig. 2a). The plateau level was about 9.36-fold higher than the baseline circulating level (Fig. 2a, the negative control group, $185 \mathrm{CFUs} / \mathrm{mL}$ ). The mobilizing efficacy of HF51116 was comparable to AMD3100 [29] at a dose of $5 \mathrm{mg} / \mathrm{kg}$. In comparison with the negative control group, HF51116 induced 8.73-fold increases in CFU-GM (1035/mL), 11.01-fold increases in BFU-E $(698 / \mathrm{mL})$, and 9.75 -fold increases in CFUGEMM (33/mL) numbers in PB (Fig. 2b).

CFUs were also rapidly increased at $15 \mathrm{~min}$ after HF51116 treatment and reached a pick level at $30 \mathrm{~min}$, 9.57-fold higher than the level in PB collected before HF51116 injection (Fig. 2c, the Before group, 198 CFUs/ $\mathrm{mL}$ ). The mobilization efficacy of HF51116 was comparable 


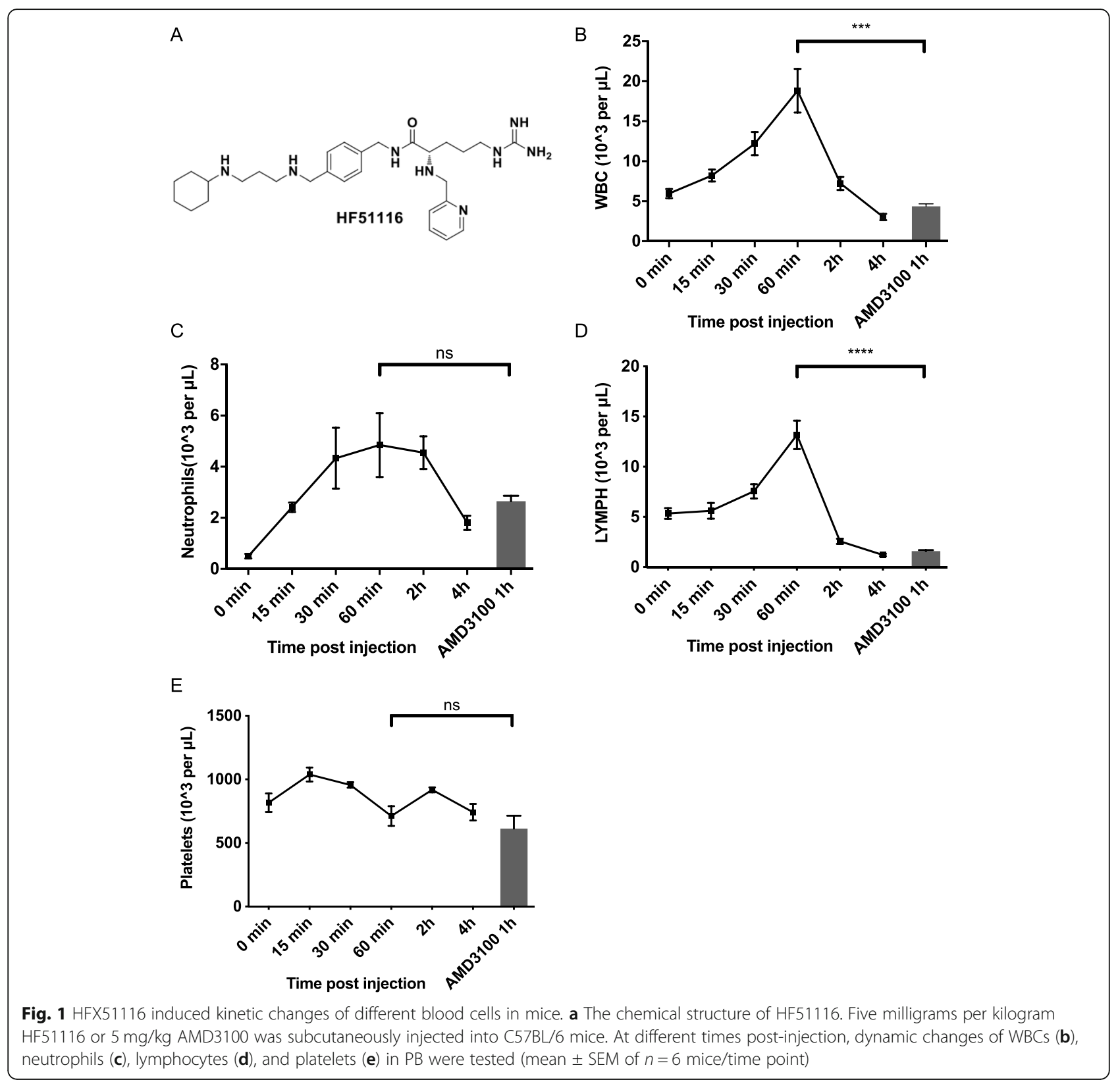

to that of AMD3100 from $15 \mathrm{~min}$ to $1 \mathrm{~h}$ post-injection (Fig. 2c). The PB also showed time-dependent changes in CFU-GMs, BFU-Es, and CFU-GEMMs in response to HF51116 (Fig. 2d).

Inter-individual variability in the mobilizations of HPCs in patients means that approximately $15 \%$ of patients are insensitive to G-CSF [18]. This phenomenon also exists in different mouse strains [9]. We used $\mathrm{C} 57 \mathrm{BL} / 6, \mathrm{C} 3 \mathrm{H} / \mathrm{HEJ}$, and $\mathrm{DBA} / 2$ mice to test the variability in HF51116 response and sensitivity to HF51116 in different mouse strains (Fig. 2e). At $30 \mathrm{~min}$ postinjection of $5 \mathrm{mg} / \mathrm{kg}$ HF51116, C57BL/6 and C3H/HEJ strains showed comparable sensitivities, but DBA/2 strain exhibited the better sensitivity than C57BL/6 strain.

\section{Synergistic mobilization by HF51116 and G-CSF}

After confirming the optimal dose and time for HPC mobilization, we tested the potential for synergistic effects of co-administration efficiency of G-CSF+HF51116.

G-CSF, G-CSF+HF51116, or G-CSF+AMD3100 were subcutaneously injected into mice. The mobilization efficacy in the G-CSF+HF51116 group (24,963 CFUs/mL) was 5.50-fold higher than that in the G-CSF group (4538 CFUs/mL) and 1.35-fold higher than that in G-CSF+ AMD3100 group $(18,512 \mathrm{CFUs} / \mathrm{mL})$ (Fig. 3a). We 


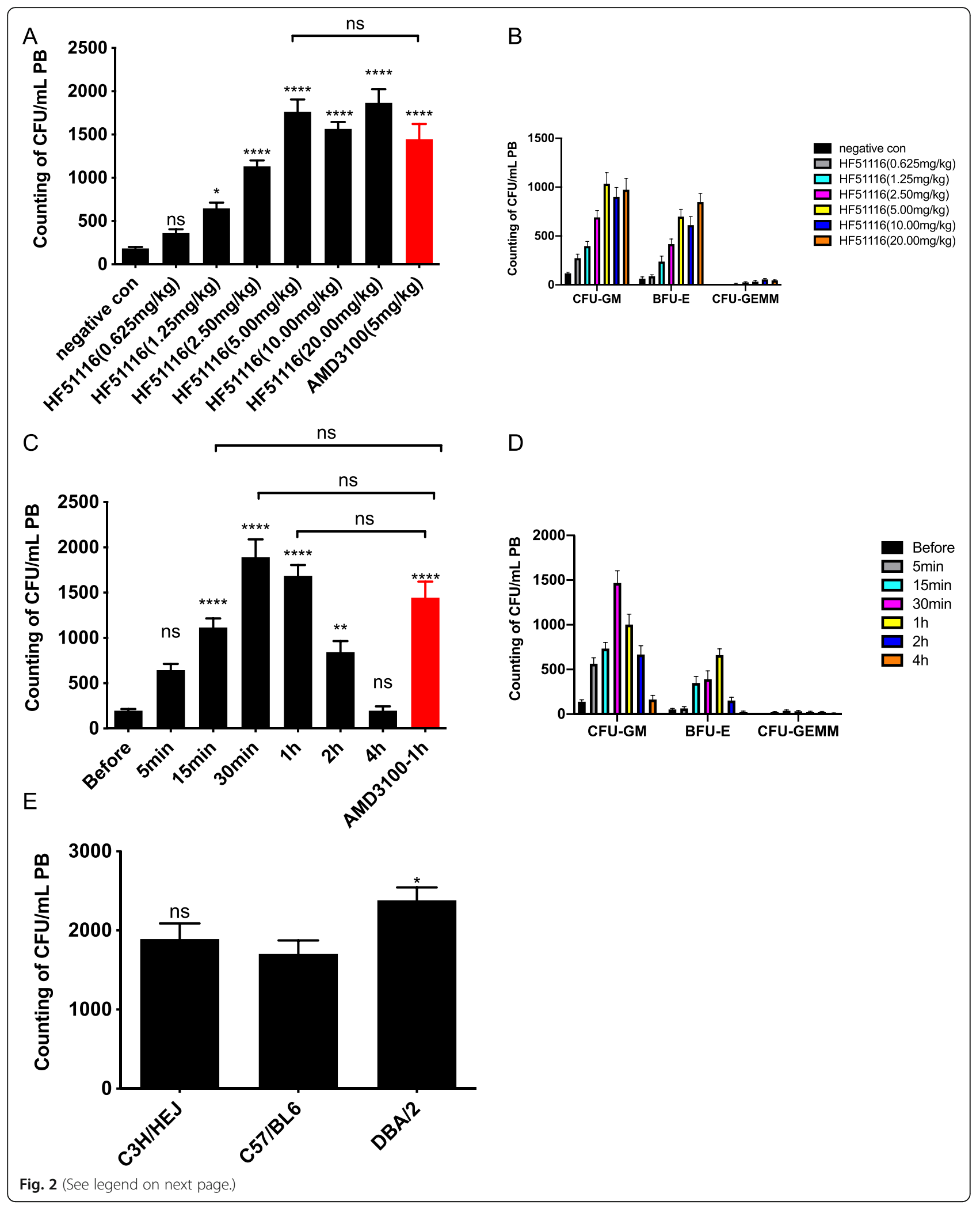


(See figure on previous page.)

Fig. 2 Mobilization of murine HPCs by HF51116. a, b The dose-dependent response of HF51116 in C3H/HEJ mice. HF51116 was given at different doses and AMD3100 was given at $5 \mathrm{mg} / \mathrm{kg}$. The negative control group received saline only. Blood samples were collected at $1 \mathrm{~h}$ post-injection. a Sum of CFUs at different doses. $\mathbf{b}$ Composition of CFUs at different doses (mean \pm SEM of $n=12$ mice/group/dose). $\mathbf{c}$, $\mathbf{d}$ Dynamic change of efficacy at different times following subcutaneous (s.c.) injections of HF51116 (5 mg/kg) or AMD3100 (5 mg/kg) into C3H/HEJ mice. HF51116 and AMD3100 were given at the same dose. CFU numbers were measured at different times for HF51116 and at $1 \mathrm{~h}$ for AMD3100. c Sum of CFUs at different times. $\mathbf{d}$ Composition of CFUs at different times (mean \pm SEM of $n=10$ mice/time point, $n=9$ mice for $4 \mathrm{~h}, n=12$ mice for the AMD3100 group). e Inter-individual variability in different mouse strains. Five milligrams per kilogram HF51116 was subcutaneously (s.c.) injected into C57BL/6, C3H/HEJ, and DBA/2 mice. The blood samples were collected at 30 min post-injection (mean \pm SEM of $n=12$ mice for the C57BL/6 and DBA/2 groups, $n=10$ mice for the $\left(3 \mathrm{H} / \mathrm{HEJ}\right.$ group). ${ }^{* * *} P<0.0001,{ }^{* *} P<0.01,{ }^{*} P<0.05$; ns, not significant

simultaneously examined the absolute number of hematopoietic stem and progenitor cells (HSPCs, Lineage $^{-} \mathrm{Sca}_{-1}{ }^{+} \mathrm{c}-\mathrm{Kit}^{+}$: LSK) and HSCs $\left(\mathrm{CD} 150^{+} \mathrm{CD}^{-} 8^{-}\right.$ lineage ${ }^{-} \mathrm{Sca}_{-}{ }^{+} \mathrm{C}^{-\mathrm{Kit}^{+}}$: SLAM LSK) in PB mobilized by these three treatments [30]. The absolute number of LSK cells in the G-CSF+HF51116 group and G-CSF group were $8612 / \mathrm{mL}$ and $2024 / \mathrm{mL}$, respectively (Fig. 3b, c). In addition, the absolute number of SLAM-LSK cells in the G-CSF+HF51116 group and G-CSF group were $715 / \mathrm{mL}$ and $214 / \mathrm{mL}$, respectively (Fig. 3d, e). A tendency to a higher absolute number of LSK and SLAM-LSK cells in the G-CSF+HF51116 group was observed.

\section{Long-term repopulating and self-renewing capability of HSPCs and HSCs mobilized by G-CSF and HF51116}

We also evaluated the long-term repopulating and selfrenewing ability of HSPCs and HSCs post-injection of G-CSF+HF51116. The recovery of neutrophils and platelets was reflected in the engraftment kinetics, as the HSPCs and HSCs mobilized by G-CSF+HF51116 treatment showed timely and early engraftment (Fig. $4 \mathrm{a}-\mathrm{c}$ ). Lethally irradiated $\mathrm{CD} 45.1^{+}$recipients receiving lightdensity mononuclear cells (LDMNCs) obtained from $\mathrm{PB}$ mobilized by G-CSF, G-CSF+AMD3100, and G-CSF+ HF51116 (Fig. 4a) showed similar engraftment kinetics: neutrophils recovered to the baseline level at around 18 days (Fig. 4b) and platelets recovered at around 35 days (Fig. 4c).

We employed CD45 congenic mice to demonstrate the long-term repopulating ability of HSPCs and HSCs (Fig. 4d). The percentage of CD45.2 $2^{+}$cells in the GCSF+HF51116 (73.50\%) group was 2.0-fold higher than in the G-CSF group (35.44\%) and 1.3-fold higher than in the G-CSF+AMD3100 (54.60\%) group post 6 months transplantation (Fig. 4e). We also collected CD45.1/ CD45.2 mouse BM cells and tested self-renewal of the long-term repopulated cells in a noncompetitive pattern of secondary transplantation (Fig. 4d). There was no significant difference of the percentage of CD45.2 $2^{+}$cells between G-CSF+HF51116 (79.11\%) and G-CSF+AMD3100 (70.98\%) groups; the percentage of $\mathrm{CD} 45.2^{+}$cells was still 2.0-fold higher in the G-CSF+HF51116 group than in the G-CSF group (41.76\%) after 6 months post- transplantation (Fig. 4f). These data confirmed that the HSPCs and HSCs mobilized by G-CSF+HF51116 not only produce timely and early engraftment but they also retain a long-term repopulating and self-renewing capability.

\section{Mobilization of different peripheral blood cells in monkeys}

We addressed mobilization activity of HF51116 in monkeys [31]. HF51116 was subcutaneously injected into rhesus monkeys at 10 or $1 \mathrm{mg} / \mathrm{kg}$. Kinetics of WBCs, neutrophils, and lymphocytes were in time-dependent manners (Fig. 5a-c). A maximum number of WBCs was achieved at $2 \mathrm{~h}$ (Fig. 5a). HF51116 induced a 3.73-fold $(10 \mathrm{mg} / \mathrm{kg})$ change in WBC numbers when compared to 0 min (average $8.87 \mathrm{~K} / \mu \mathrm{L}$ ) with the $P$ value of 0.0015 . Neutrophil numbers reached the highest level at $4 \mathrm{~h}$ post-injection of $10 \mathrm{mg} / \mathrm{kg}$ and $1 \mathrm{mg} / \mathrm{kg}$ of HF51116 (Fig. 5b). Lymphocytes showed the maximum increases in number at $2 \mathrm{~h}$ for both doses (Fig. 5c), similar to the WBC response. However, lymphocyte numbers decreased quickly from 2 to $8 \mathrm{~h}$ and had reached $70 \%$ of the 0 -min value by $24 \mathrm{~h}$. HF51116 did not induce changes in platelets when compared to 0 min at either dose, similar to the change in mouse (Figs. 5d and 1d).

\section{Mobilization of HSCs in monkeys}

We examined the $\mathrm{CD}^{+} 4^{+}$cell counts $[32,33]$ in the $\mathrm{PB}$ in monkeys (Fig. 6a) [34] and determined that the HF51116-induced HPC mobilization was time dependent (Fig. 6b). Two hours post-injection of 10 $\mathrm{mg} / \mathrm{kg}$ HF51116, there were $17 \mathrm{CD}^{+} 4^{+}$cells $/ \mu \mathrm{L} \mathrm{PB}$. The area under the curve (AUC) was 38.47 for dose $1 \mathrm{mg} / \mathrm{kg}$ and 61.50 for dose $10 \mathrm{mg} / \mathrm{kg}$ (Fig. 6a). At $2 \mathrm{~h}$ post-injection, 10 (5900 CFUs/mL) or $1 \mathrm{mg} / \mathrm{kg}$ (4373 CFUs/mL) HF51116 produced maximum HPC mobilization effects at the same time point when WBCs and $\mathrm{CD}^{+}{ }^{+}$cells reached their maximum numbers. One milligram per kilogram HF51116 induced an approximately 8.5 -fold increase when compared to $0 \mathrm{~min}(510 \mathrm{CFUs} / \mathrm{mL})$ with the $P$ value of 0.0251 (Fig. 6b). 


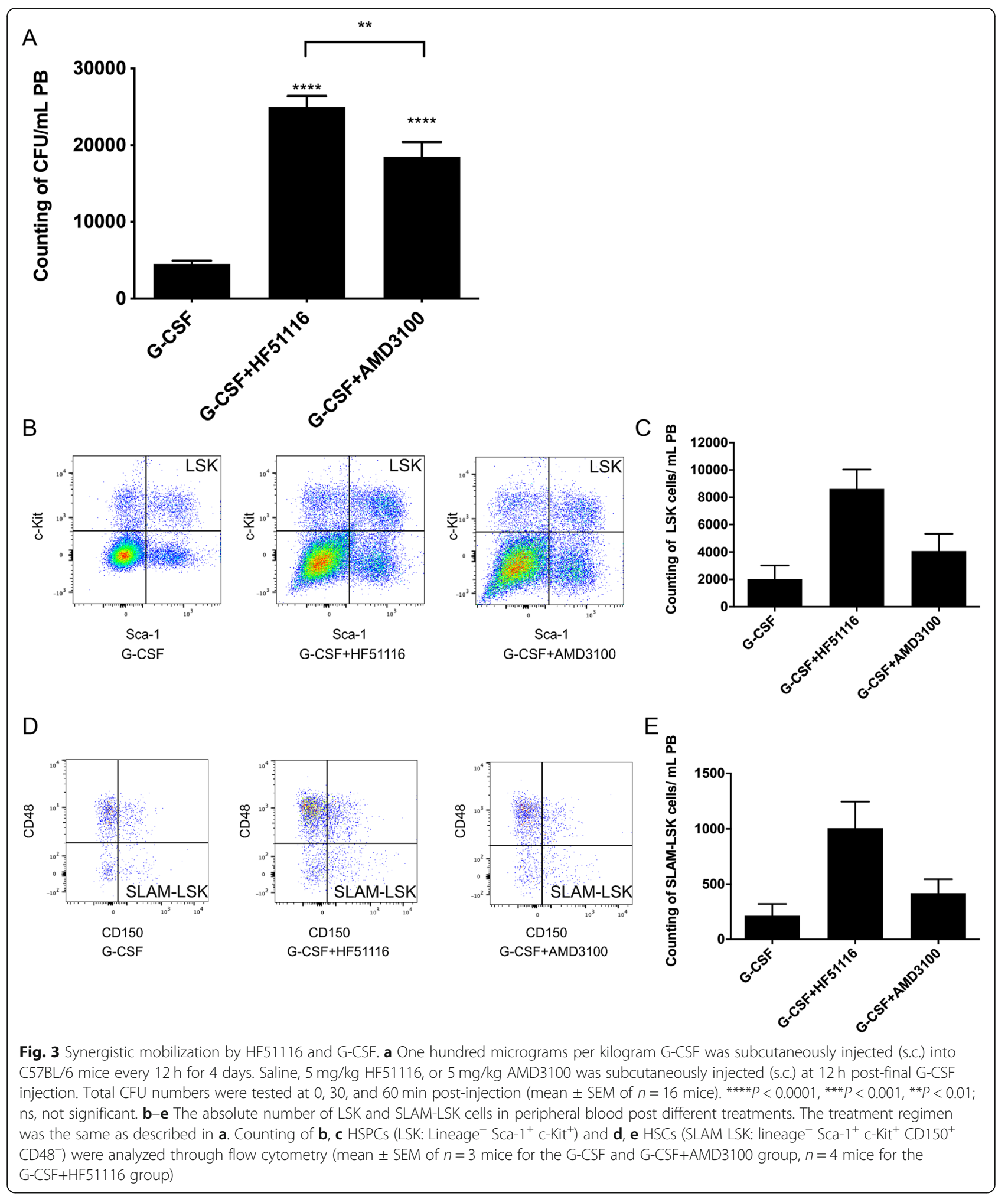

At $10 \mathrm{mg} / \mathrm{kg}$, the highest concentration of HF51116 $(6305.89 \mathrm{ng} / \mathrm{mL})$ in the PB plasma occurred at $15 \mathrm{~min}$ post-injection (Fig. 6c), and $100.54 \mathrm{ng} / \mathrm{mL}$ remained in the plasma at $24 \mathrm{~h}$. At $1 \mathrm{mg} / \mathrm{kg}$, the highest concentration $(704.641 \mathrm{ng} / \mathrm{mL})$ of HF51116 appeared at $30 \mathrm{~min}$ and no HF51116 remained in the plasma $8 \mathrm{~h}$ later. 


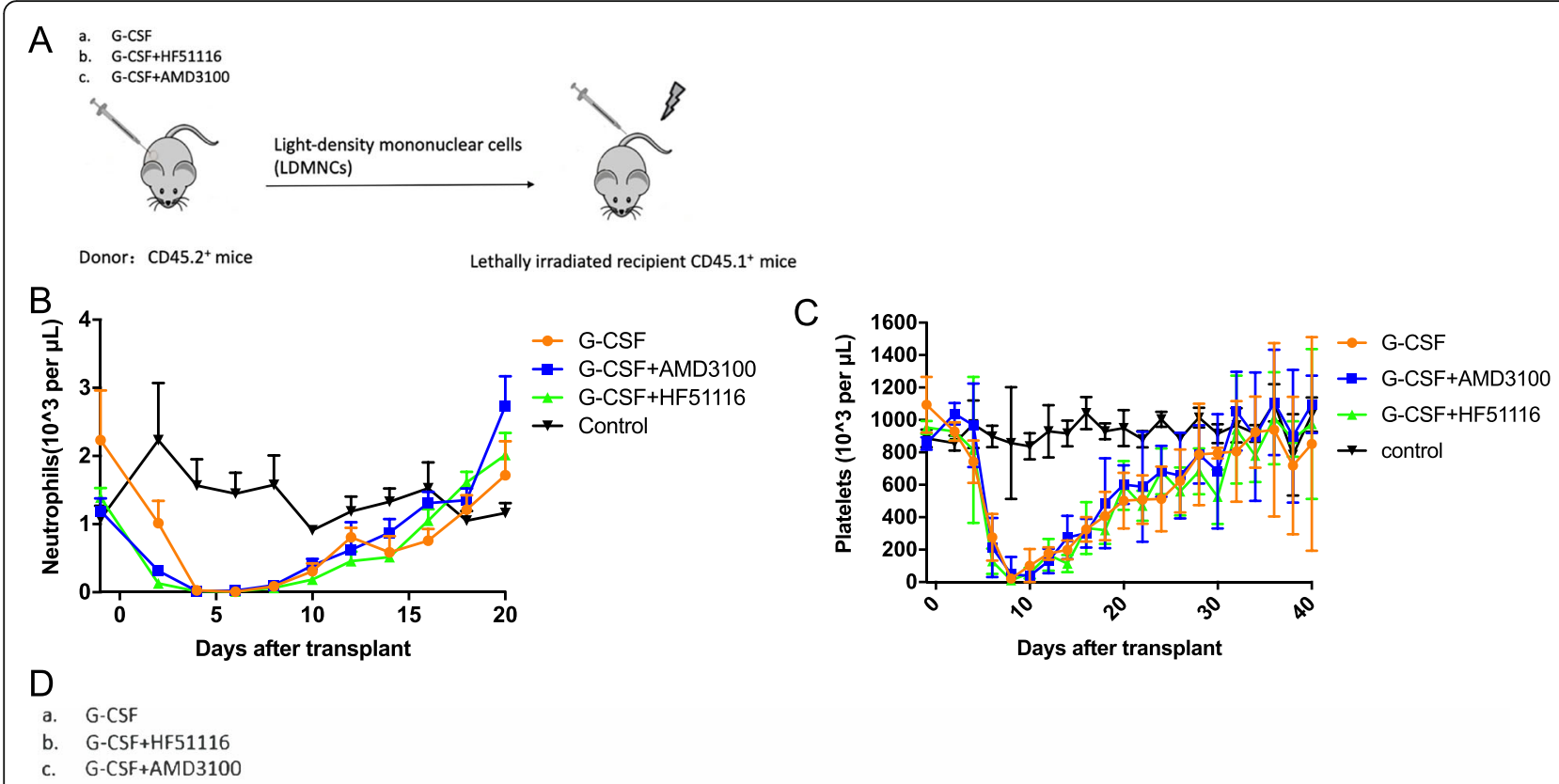

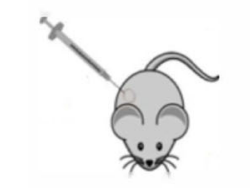

Donor: CD45. $2^{+}$mice

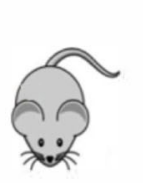

Competitor: CD $45.1^{+}$mice

E

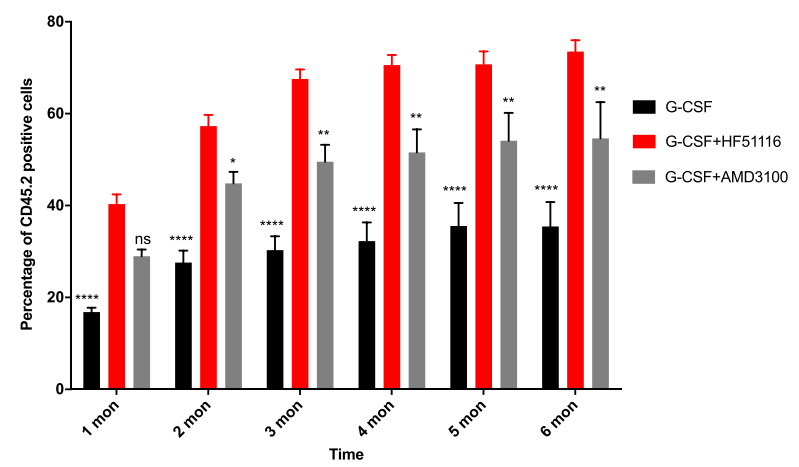

Light-density mononuclear cells (LDMNCs) from PB of CD45.2 $2^{+}$mice

BM cells from $C D 45.1^{+}$mice
Lethally irradiated recipient CD45.1/.2 mice

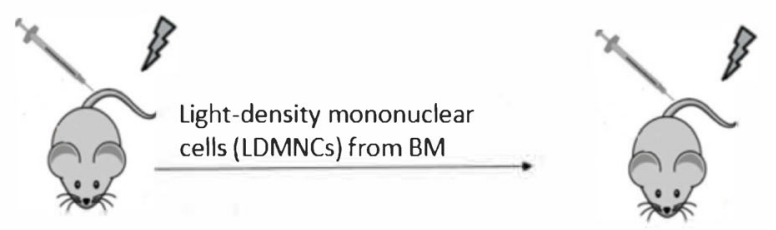

Lethally irradiated recipient CD45.1/.2 mice
$\mathrm{F}$

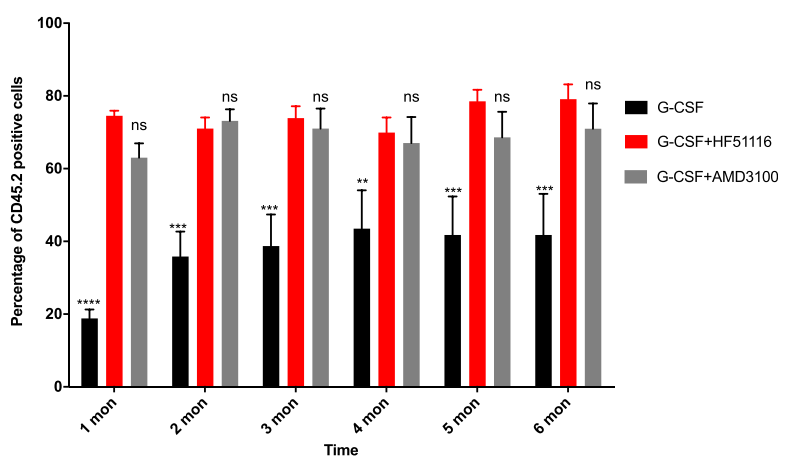

Fig. 4 (See legend on next page.) 
(See figure on previous page.)

Fig. 4 Engraftment kinetics and long-term repopulating capability of HPCs mobilized by HF51116+G-CSF. a Early engraftment strategy. G-SCF $\left(100 \mu \mathrm{g} / \mathrm{kg}\right.$, every $12 \mathrm{~h}$ for 4 days) was subcutaneously injected into CD45.2 ${ }^{+}$mice. At $12 \mathrm{~h}$ post-final G-CSF injection, saline, $5 \mathrm{mg} / \mathrm{kg} \mathrm{HF} 51116$, or $5 \mathrm{mg} / \mathrm{kg}$ AMD3100 was subcutaneously injected into the CD45.2 ${ }^{+}$mice. Light-density mononuclear cells (LDMNCs) were collected in PB at 0, 30, and 60 min post-injection of each of these agents. Lethally irradiated CD45. $1^{+}$recipients received a graft of LDMNCs. The control group was healthy mice with no radiation. The recoveries of neutrophils (b) and platelets (c) were monitored every 2 days for 40 days (mean \pm SEM of $n=10$ mice/group). d Competitive repopulation assay strategy using CD45 congenic mice. G-CSF, G-CSF+HF51116, or G-CSF+AMD3100 were injected into CD45.2 mice. Drug administration strategy was the same as used in a. BM cells from CD45.1 mice and LDMNCs from CD45.2 mice were isolated. The competitor cell number (CD45.1 $1^{+}$cells) was $0.5 \times 10^{6}$, and the donor cell number (CD45.2 $2^{+}$cells) was $1.0 \times 10^{6}$. Cell suspension containing donor and competitor cells $\left(1.5 \times 10^{6}\right.$ cells) was intravenously injected into lethally irradiated (11 Gy, $5.5 \mathrm{~Gy}$ split dose, $2 \mathrm{~h}$ apart, radiation rate $1.05 \mathrm{~Gy} / \mathrm{min}$ ) CD45.1/CD45.2 recipients. e The percentages of CD $45.2^{+}$cells were checked for 6 months (mean \pm SEM of $n=7$ mice). f The secondary repopulation in a noncompetitive assay. At 6 months post-injection, lethally secondary irradiated CD45.1/CD45.2 mice received the BM cells of every group of recipients (e) in a noncompetitive assay. The percentage of CD45.2 ${ }^{+}$was checked every month (mean \pm SEM of $n=7$ mice). ${ }^{* * *} P<0.0001,{ }^{* *} P<0.001,{ }^{* *} P<0.01,{ }^{*} P<0.05$; ns, not significant

\section{Discussion}

Blocking the SDF-1 $\alpha / C X C R 4$ axis can elicit rapid mobilization of HSCs from the BM to the PB in clinical practice [35], as demonstrated by the clinically approved CXCR4 antagonist AMD3100 [29]. Our recent efforts in developing new CXCR4 antagonists led to the discovery of HF51116 [25], a novel small molecule which strongly and specifically binds CXCR4 and effectively blocks SDF-1 $\alpha$-induced CXCR4 $4^{+}$cell migration and calcium influx (unpublished results).

For in vivo efficacy, we assessed the dose-dependent and time-dependent responses in $\mathrm{C} 3 \mathrm{H} / \mathrm{HEJ}$ mice and the mobilization effect in three different mouse strains. $\mathrm{DBA} / 2$ mice were more sensitive than $\mathrm{C} 57 \mathrm{BL} / 6$ mice to HF51116. This variation resembles the situation of interindividual variability in human patients and in mice in response to POL5551 [36]. Our investigation of the in vivo efficacy for mobilizing HPCs in both mice and monkeys confirmed that HF51116 consistently and significantly mobilized CFUs from the BM to the PB. The HSC mobilization efficacy of HF51116 and AMD3100 was compared in mice. The HF51116induced mobilization of HPCs was dose and time dependent. At $5 \mathrm{mg} / \mathrm{kg}$, the number of CFUs mobilized at 15 min post-injection of HF51116 was the same as that achieved at $1 \mathrm{~h}$ post-injection of AMD3100. Therefore, HF51116 might be a potential alternative to AMD3100 for patients who do not respond to AMD3100. In monkeys, the maximum $\mathrm{CD}_{4} 4^{+}$cell and CFU mobilization effects also occurred at $2 \mathrm{~h}$. The kinetics of WBC, neutrophil, and lymphocyte mobilization by HF51116 were also time and dose dependent. HF51116 could induce the increase of neutrophils in $\mathrm{PB}$ for a long time in mice and monkeys. On the other hand, the
A

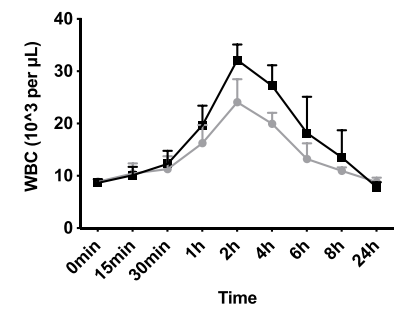

C

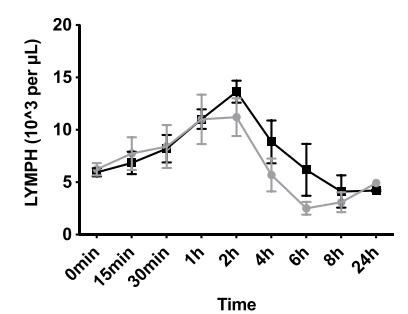

B

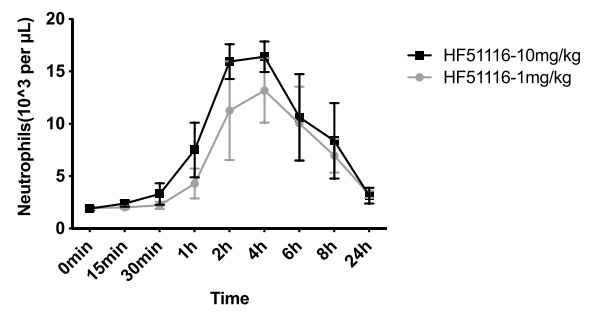

D

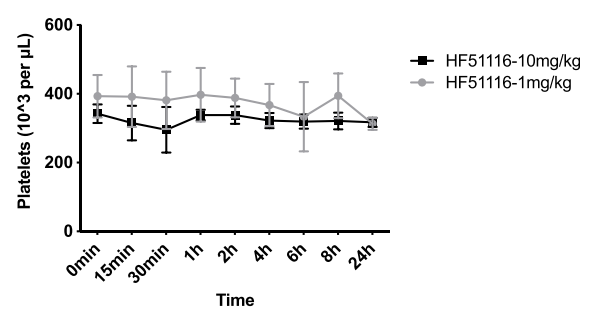

Fig. 5 Kinetics of different blood cells mobilized by HF51116 in monkeys. The dynamic changes of WBCs (a), neutrophils (b), lymphocytes (c), and platelets (d) in peripheral blood following subcutaneously injections of 10 or $1 \mathrm{mg} / \mathrm{kg}$ HF51116 into rhesus monkeys. Blood samples were collected at different times post-injection (mean \pm SEM of $n=3$ rhesus monkeys/group/time point) 


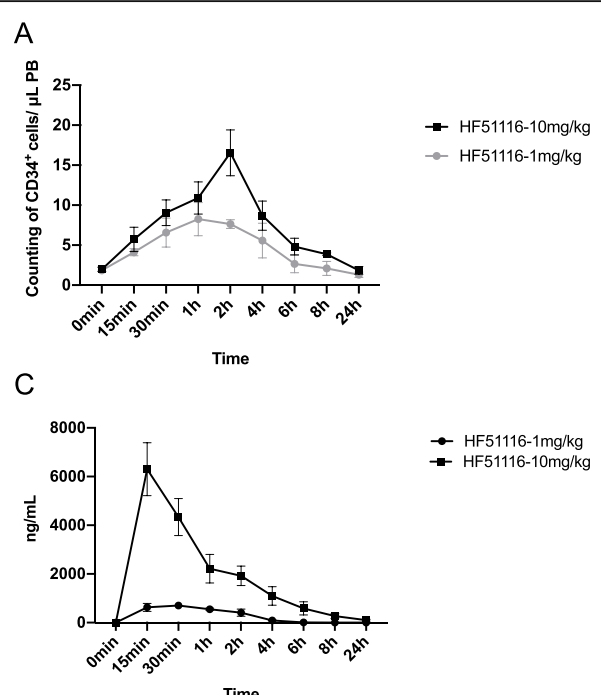

\section{B}

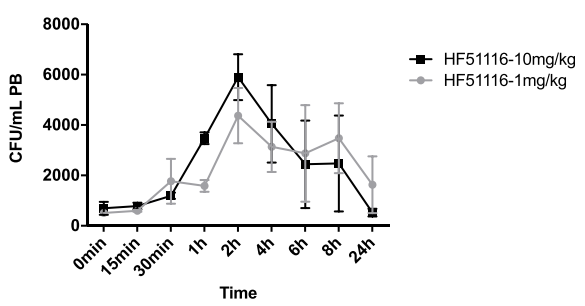

Fig. 6 Mobilization efficacy and PK properties of HF51116 in monkeys. HF51116 at 10 and $1 \mathrm{mg} / \mathrm{kg}$ were subcutaneously injected into rhesus monkeys. Blood samples were collected at different times post-injection. $\mathbf{a}$, b Time response of CD34 $4^{+}$cells and HPCs in monkeys. c Concentration changes of HF51116 in PB (mean \pm SEM of $n=3$ rhesus monkeys/group/time point)

numbers of platelets in PB remained unchanged in mice and monkeys after HF51116 injection. HF51116 reached the highest blood concentration at 15 min post-injection and was subsequently removed from the blood circulation quickly in monkeys.

The repopulating activity was studied by examining the effect of HF51116 on the long-term repopulation in CD45 congenic mice. HF51116 dramatically synergized the mobilizing capacity of G-CSF after co-administered into these mice. In noncompetitive assays, HSCs and HSPCs mobilized by HF51116+G-CSF provided timely engraftment. In competitive assays, the percentage of CD45.2 ${ }^{+}$cells was higher in the HF51116+G-CSF group than in the G-CSF and AMD3100+G-CSF groups in the primary transplant. Treatment by G-CSF may either elicit inflammatory signals or promote HSC proliferation to increase the mobilizable HSC pools. HF51116 acts on the SDF- $1 \alpha / C X C R 4$ axis and mobilizes more HSCs than using G-CSF alone. G-CSF shows inter-individual variability and causes bone pain due to its toxic side effects on the BM microenvironment $[37,38]$, and it requires a 4-day standard treatment, which could be too long. The stronger HSC mobilization activity of HF51116 plus GCSF was clearly demonstrated in the primary transplant and the activity was similar with AMD3100 plus G-CSF in the secondary transplant. This short-term higher HSC mobilization activity of HF51116 plus G-CSF might represent a possible option for patients who suffer from the side effects of chemotherapy. In addition, the combination of HF51116 with other drugs such as proteasome inhibitors [39, 40], GRO $\beta[34,41,42]$, or Viagra [43] is worth investigating to find even better and shorter HSC mobilization regimens.

\section{Conclusions}

In summary, we have shown that a novel CXCR4 antagonist HF51116 is a potent HSC mobilizer and can rapidly and sufficiently mobilize HSCs from BM to the PB in mice and monkeys. HF51116 not only mobilizes HSCs when used alone, but also synergizes with G-CSF when co-administered. The HSCs mobilized by HF51116 have long-term repopulating activity and are sufficient for engrafting in primary and secondary lethally irradiated mice, where they rescue and support the survival of the animals. In monkeys, HF51116 exhibits strong HPC mobilization activity and is removed from the circulation quickly. These results demonstrate that HF51116 represents a novel and potent HSC mobilizer that targets CXCR4 and has promising potential for clinical applications.

\section{Abbreviations}

BM: Bone marrow; BMSCs: Bone marrow stromal cells; BFU-E: Burst-forming unit-erythroid; CFU-GEMM: Colony-forming unit-granulocyte, erythroid, megakaryocyte, and macrophage; CFU-GM: Colony-forming unit-granulocytemacrophage; CXCR4: CXC chemokine receptor 4; G-CSF: Granulocyte colonystimulating factor; HSPC: Hematopoietic stem and progenitor cell;

HSCs: Hematopoietic stem cells; HSCT: Hematopoietic stem cell transplantation; LTR: Long-term repopulating; PB: Peripheral blood; SDF1a: Stromal cell-derived factor-1a; WBCs: White blood cells

\section{Acknowledgements}

The authors thank the Laboratory Animal Research Center at Tsinghua University and the Institute of Laboratory Animals Science, CAMS \& PUMC, for helping with animal feeding; the Cell Biology Facility and Institute for Immunology at Tsinghua University for the use of flow cytometers; the Proteomics and Metabolomics Core Facility at Tsinghua University for the help of pharmacokinetic assays; the Dr. Xiuqin Zhang Lab from the Institute of Molecular Medicine at Peking University for the use of ProCyte Dx Hematology Analyzer (IDEXX); and the labs of Drs. Li Wu, Hai Qi, Zhongjun Dong, Jie Na, and Wei Guo from the School of Medicine at Tsinghua 
University for sharing B6.SJL-Ptprc ${ }^{a}$ Pepc $c^{b}$ BoyJ mice $\left(C^{2} 45.1^{+}\right)$and providing useful discussion and comments.

\section{Authors' contributions}

Xiao Fang designed and performed the experiments, analyzed the data, and wrote the manuscript. Xiong Fang designed and synthesized the CXCR4 antagonist HF51116. Yan Xu, Yujia Mao, Aaron Ciechanover, Jing An, and Ziwei Huang discussed the research designs and results. Jing An and Ziwei Huang oversaw this study and revised the manuscript. All authors read and approved the manuscript.

\section{Funding}

This work was supported by grants from Tsinghua University.

\section{Availability of data and materials}

The data and materials are available from the corresponding authors upon request.

\section{Ethics approval and consent to participate}

The laboratory animal facility has been accredited by AAALAC (Association for Assessment and Accreditation of Laboratory Animal Care International) and the IACUC (Institutional Animal Care and Use Committee) of Tsinghua University. It approved all mouse animal protocols used in this study with IACUC number $17 \mathrm{HZW}-1$.

Male rhesus macaques (4-6 years old) were housed in individual cages in conventional holding rooms at the Institute of Laboratory Animals Science, Chinese Academy of Medical Sciences (CAMS) and Peking Union Medical College (PUMC), which had been accredited by AAALAC. The protocol was approved by the same institute with IACUC number XC19006.

\section{Consent for publication}

Not applicable.

\section{Competing interests}

The authors declare no competing interests.

\section{Author details}

${ }^{1}$ School of Life Sciences, Tsinghua University, Beijing, China. ${ }^{2}$ The Rapport Faculty of Medicine, Technion-Israel Institute of Technology, 3109601 Haifa, Israel. ${ }^{3}$ Nobel Institute of Biomedicine, Zhuhai 519080, China. ${ }^{4}$ Ciechanover Institute of Precision and Regenerative Medicine, School of Life and Health Sciences, Chinese University of Hong Kong, Shenzhen, China. ${ }^{5}$ Division of Infectious Diseases and Global Public Health, Department of Medicine, School of Medicine, University of California at San Diego, La Jolla, CA, USA.

\section{Received: 25 July 2020 Accepted: 6 December 2020}

Published online: 07 January 2021

\section{References}

1. Choi WT, Duggineni $S, X u Y$, Huang Z, An J. Drug discovery research targeting the CXC chemokine receptor 4 (CXCR4). J Med Chem. 2012;55(3): 977-94.

2. Wu F, Song G, de Graaf C, Stevens RC. Structure and function of peptidebinding G protein-coupled receptors. J Mol Biol. 2017;429(17):2726-45.

3. Wu B, Chien EYT, Mol CD, Fenalti G, Liu W, Katritch $V$, et al. Structures of the CXCR4 chemokine GPCR with small-molecule and cyclic peptide antagonists. Science. 2010;330(6007):1066-71.

4. Busillo JM, Benovic JL. Regulation of CXCR4 signaling. Biochim Biophys Acta Biomembr. 2007:1768(4):952-63.

5. Teicher BA, Fricker SP. CXCL12 (SDF-1)/CXCR4 pathway in cancer. Clin Cancer Res. 2010;16(11):2927-31.

6. Lapidot T, Kollet O. The essential roles of the chemokine SDF-1 and its receptor CXCR4 in human stem cell homing and repopulation of transplanted immune-deficient NOD/SCID and NOD/SCID/B2m null mice. Leukemia. 2002;16(10):1992-2003

7. Peled A, Petit I, Kollet O, Magid M, Ponomaryov T, Byk T, et al. Dependence of human stem cell engraftment and repopulation of NOD/SCID mice on CXCR4. Science. 1999:283(5403):845-8

8. Christopherson KW, Hangoc G, Mantel C, Broxmeyer HE. Modulation of hematopoietic stem cell homing and engraftment by CD26. Science. 2004; 305(5686):1000-3.
9. $\mathrm{Ma} Q$, Jones $\mathrm{D}$, Springer TA. The chemokine receptor CXCR4 is required for the retention of $B$ lineage and granulocytic precursors within the bone marrow microenvironment. Immunity. 1999;10(4):463-71.

10. Shen H, Cheng T, Olszak IT, Garciazepeda EA, Lu Z, Herrmann SH, et al. CXCR-4 desensitization is associated with tissue localization of hemopoietic progenitor cells. J Immunol. 2001;166(8):5027-33.

11. Hattori K, Heissig B, Tashiro K, Honjo T, Tateno M, Shieh J, et al. Plasma elevation of stromal cell-derived factor-1 induces mobilization of mature and immature hematopoietic progenitor and stem cells. Blood. 2001;97(11):3354-60.

12. Petit I, Szyperkravitz M, Nagler A, Lahav M, Peled A, Habler L, et al. G-CSF induces stem cell mobilization by decreasing bone marrow SDF-1 and upregulating CXCR4. Nat Immunol. 2002;3(7):687-94.

13. Lévesque JP, Hendy J, Takamatsu Y, Simmons PJ, Bendall L. Disruption of the CXCR4/CXCL12 chemotactic interaction during hematopoietic stem cell mobilization induced by GCSF or cyclophosphamide. J Clin Invest. 2003; 111(2):187-96

14. Nervi B, Link DC, DiPersio JF. Cytokines and hematopoietic stem cell mobilization. J Cell Biochem. 2006;99(3):690-705.

15. Semerad CL, Christopher MJ, Liu F, Short B, Simmons PJ, Winkler IG, et al. GCSF potently inhibits osteoblast activity and CXCL12 mRNA expression in the bone marrow. Blood. 2005;106(9):3020-7.

16. Gertz MA. Current status of stem cell mobilization. Br J Haematol. 2010;150: 647-62

17. Pastore D, et al. Good and poor CD34+ cells mobilization in acute leukemia: analysis of factors affecting the yield of progenitor cells. Bone Marrow Transplant. 2004;33:1083-7.

18. Roberts AW, DeLuca E, Begley CG, Basser R, Grigg AP, Metcalf D. Broad inter-individual variations in circulating progenitor cell numbers induced by granulocyte colony-stimulating factor therapy. Stem Cells. 1995;13(5):512-6.

19. De Haan G, Ausema A, Wilkens M, Molineux G, Dontje B. Efficient mobilization of haematopoietic progenitors after a single injection of pegylated recombinant human granulocyte colony-stimulating factor in mouse strains with distinct marrow-cell pool sizes. Br J Haematol. 2000; 110(3):638-46.

20. Croop JM, Cooper R, Fernandez C, Graves V, Kreissman SG, Hanenberg H, et al. Mobilization and collection of peripheral blood CD34+ cells from patients with Fanconi anemia. Blood. 2001;98(10):2917-21.

21. De Clerca E. Mozobil ${ }^{\oplus}$ (Plerixafor, AMD3100), 10 years after its approval by the US Food and Drug Administration. Antivir Chem Chemother. 2019;27: 2040206619829382

22. Hendrix CW, Flexner CW, Macfarland RT, Giandomenico C, Fuchs EJ, Redpath E, et al. Pharmacokinetics and safety of AMD-3100, a novel antagonist of the CXCR-4 chemokine receptor, in human volunteers. Antimicrob Agents Chemother. 2000;44(6):1667-73.

23. Lemery SJ, et al. A pilot study evaluating the safety and CD34+ cell mobilizing activity of escalating doses of plerixafor in healthy volunteers. Bri J Haematol. 2011:153:66-75.

24. Fang X, Meng Q, Fang X, Mao Y, Xu Y, An J, et al. Abstract 2181: A nove CXCR4 antagonist strongly mobilizes hematopoietic stem cells in vivo. Cancer Res. 2019;79(13 Supplement):2181

25. Fang $X$, Meng $Q$, Fang $X$, Zhu S, Huang $Y$, An J, et al. Abstract 4: Discovery of novel and highly potent small molecule inhibitors of chemokine receptor CXCR4. Cancer Res. 2019:79(13 Supplement):4.

26. Herbert K, Levesque J, Haylock DN, Prince M. The use of experimental murine models to assess novel agents of hematopoietic stem and progenitor cell mobilization. Biol Blood Marrow Transplant. 2008;14(6):603-21.

27. Lemos NE, Farias MG, Kubaski F, Scotti L, Onsten TGH, Brondani LDA, et al. Quantification of peripheral blood CD34+ cells prior to stem cell harvesting by leukapheresis: a single center experience. Hematol Transfusion Cell Ther. 2017:40(3):213-8.

28. Fang X, Meng Q, Zhang H, Liang B, Zhu S, Wang J, et al. Design, synthesis, and biological characterization of a new class of symmetrical polyaminebased small molecule CXCR4 antagonists. Eur J Med Chem. 2020;200: 112410

29. Broxmeyer HE, Orschell CM, Clapp DW, Hangoc G, Cooper S, Plett PA, et al. Rapid mobilization of murine and human hematopoietic stem and progenitor cells with AMD3100, a CXCR4 antagonist. J Exp Med. 2005;201(8): 1307-18.

30. Kumar R, Fossati V, Israel MA, Snoeck H. Lin-Sca1+kit- bone marrow cells contain early lymphoid-committed precursors that are distinct from common lymphoid progenitors. J Immunol. 2008;181(11):7507-13. 
31. Peng S, Van Horn RD, Yin T, Brown RM, Roell WC, Obungu VH, et al. Distinct mobilization of leukocytes and hematopoietic stem cells by CXCR4 peptide antagonist LY2510924 and monoclonal antibody LY2624587. Oncotarget. 2017:8(55):94619-34.

32. Hoggatt J, Mohammad KS, Singh P, Hoggatt AF, Chitteti BR, Speth JM, et al. Differential stem and progenitor cell trafficking by prostaglandin E2. Nature. 2013;495(7441):365-9.

33. Hübel K, Liles WC, Broxmeyer HE, Rodger E, Wood B, Cooper S, et al. Leukocytosis and mobilization of CD34+ hematopoietic progenitor cells by AMD3100, a CXCR4 antagonist. Support Cancer Ther. 2004;1(3):165-72.

34. King AG, Horowitz D, Dillon SB, Levin RH, Farese AM, Macvittie TJ, et al. Rapid mobilization of murine hematopoietic stem cells with enhanced engraftment properties and evaluation of hematopoietic progenitor cell mobilization in rhesus monkeys by a single injection of SB-251353, a specific truncated form of the human CXC chemokine GROß. Blood. 2001; 97(6):1534-42

35. Domingues MJ, Nilsson SK, Cao B. New agents in HSC mobilization. Int J Hematol. 2017;105(2):141-52.

36. Karpova D, Dauber K, Spohn G, Chudziak D, Wiercinska E, Schulz M, et al. The novel CXCR4 antagonist POL5551 mobilizes hematopoietic stem and progenitor cells with greater efficiency than Plerixafor. Leukemia. 2013; 27(12):2322-31.

37. Gavioli E, Abrams M. Prevention of granulocyte-colony stimulating factor (GCSF) induced bone pain using double histamine blockade. Support Care Cancer. 2017;25(3):817-22.

38. Winkler IG, Pettit AR, Raggatt $L$, Jacobsen RN, Forristal CE, Barbier V, et al. Hematopoietic stem cell mobilizing agents G-CSF, cyclophosphamide or AMD3100 have distinct mechanisms of action on bone marrow HSC niches and bone formation. Leukemia. 2012;26(7):1594-601.

39. Ghobadi A, Rettig MP, Cooper ML, Holt M, Ritchey J, Eissenberg L, et al. Bortezomib is a rapid mobilizer of hematopoietic stem cells in mice via modulation of the VCAM-1NLA-4 axis. Blood. 2014;124(17):2752-4.

40. Ghobadi A, Rettig MP, Holt M, Ritchey J, Eissenberg L, Dipersio JF. Ixazomib, an oral proteasome inhibitor, induces rapid mobilization of hematopoietic stem cells in mice. Blood. 2018;126(23):513.

41. Hoggatt J, Singh P, Tate TA, Chou B-K, Datari SR, Fukuda S, et al. Rapid mobilization reveals a highly engraftable hematopoietic stem cell. Cell. 2018;172(1-2):191-204.e10.

42. Pelus LM, Bian H, King AG, Fukuda S. Neutrophil-derived MMP-9 mediates synergistic mobilization of hematopoietic stem and progenitor cells by the combination of G-CSF and the chemokines GRObeta/CXCL2 and GRObetaT/ CXCL2delta4. Blood. 2004;103(1):110-9.

43. Smith-Berdan S, Bercasio A, Rajendiran S, Forsberg EC. Viagra enables efficient, single-day hematopoietic stem cell mobilization. Stem Cell Rep. 2019;13(5):787-92.

\section{Publisher's Note}

Springer Nature remains neutral with regard to jurisdictional claims in published maps and institutional affiliations.

Ready to submit your research? Choose BMC and benefit from:

- fast, convenient online submission

- thorough peer review by experienced researchers in your field

- rapid publication on acceptance

- support for research data, including large and complex data types

- gold Open Access which fosters wider collaboration and increased citations

- maximum visibility for your research: over $100 \mathrm{M}$ website views per year

At BMC, research is always in progress.

Learn more biomedcentral.com/submissions 